\title{
テンペの機能性
}

インドネシアが世界の食文化に貢献できるとすれば，それはテンペであろうといわれている。無塩大豆発酵食 品として納豆とともに，今や世界の食品化学者から注目されている理由は，大豆臭を除去し，消化性を高めて食 べやすい食品であると同時に，抗菌性，抗酸化性などの面で優れた特性を備えているからである。これらの特性 をも含めて, 第三の機能について解説していただいた。

\section{岡 田憲幸}

\section{は じめに}

テンペは, インドネシアを発祥の地とし，その周辺の 国々だけでなく，現在では，オランダ，アメリカ，そし て日本でも作られるよらになった。テンペが注目される のは, 自然食品, 低コストの蛋白食品, 肉類のビタミン を含む菜食主義者の蛋白源，コレステロールは含まず不 飽和脂肪酸に富さ健康食品としてであるが，日本では， 納豆特有の臭いやネバネバがないことから，納豆嫌いで も食べられる納豆などとして，注目された。筆者は，テ ンペを遺伝資源とし, そこから有用微生物を分離し, 日 本の発酵食品に応用できないものかと研究しているもの であるが，ここでは，テンペについての「機能性」を紹 介する。

荒井1)によると, 食品の機能には, 一次機能, 二次機 能, 三次機能があり, 一次機能は栄養機能, 二次機能は 感覚機能, 三次機能は生体調節機能のことをいう。そし て機能性食品を, 「三次機能を効率よく発現するように 設計され, 作製される加工食品」と呼んでいる。また厚 生省設置の機能性食品懇談会 ${ }^{2}$ は, 「食品成分のもつ生体 防御, 体調りズム調節, 疾病の防止と回復等に係わる体 調調節機能を，生体に対して十分に発現できるように設 計し，加工された食品であること」と定義している。し たがってテンぺは機能性食品ではないが，「テンぺの機 能性」といった場合, 生体調節機能（三次機能）を考察 することと解される。では生体調節機能とは何か。生体 調節機能には, 生体防御系の感染防御, 制ガン, アレル ギー低減化など, ホルモン系の抗糖尿, 神経系の鎮静, 食欲制御, 循環系の造血, 降圧, 抗血栓, 消化系の抗
菌, 抗ウィルス, 抗毒, 整腸などがある1”。この場合, 好ましい因子が導入されて, 生体調節機能が付与されて もいいし，また好ましくない因子が排除されて，目的が 達成されてもよいとされている。果してテンペにそのよ らな機能性があるのであろらか，疑問があるところであ るが，以下なるべく趣旨に沿ってまとめてみたい。筆者 はこの分野には素人であり, 研究紹介にとどめる。

\section{1. テンペの抗菌作用}

一消化系の抗菌による生体調節機能一

テンペには抗生物質的作用があり，消化系の抗菌によ る生体調節機能を有しているといわれる。以下この点に ついて文献をひもといてみた。

\section{（1）第二次大戦中に果したテンぺの役割3)}

HESSELTINE は，第二次大戦中に果したテンぺの役 割について, STAHEL（1946）ならびにVAN VEEN と SCHEFER（1950）の論文をもとに，以下のことを紹介し ている。「STAHEL はスリナムの農業実験所の所長であ ったが，第二次大戦中，アメリカ合臯国からニューギニ アへ，そこにいるヨーロッパ人やインドネシア人を生き 延びさせるため, アメリカの大豆がいかに送られたかを 回顧している。最初, 輸送船関係者は, 普通の大豆は, 発酵大豆 (テンペ) に馴れ親しんでいるインドネシア人 に，受け入れられないことを知らなかった。また日本占 領時代，テンペの製造は中止されて抢り，テンペの種菌 はすっかり失われていた。そこで, STAHEL は, スリナ ムからテンペの種菌を供給するよら要請された。テンペ と種菌がニューギニアに送られた後, 初めてアメリカの 大豆は, 捕虜たちの馴れ親しんでいる発酵食品となり,

Physiological Functions of Temph

Noriyuki OKADA (Tropical Agriculture Research Center, Ministry of Agriculture, Forestry and Fisheries) 
使うことができたのであった。

次に, VAN VEEN は, テンペの栄養学的側面, なら びにインドネシア捕虜の1人として，テンペについて得 た直接体験を戦後報告している。かれは, 大豆は煮ても 軟らかくならず消化しにくいことから，大豆そのままで は,インドネシア捕虜たちに人気がないことを知った。 大豆が消化しにくいのは, 単に, 大豆にあるトリプシン インヒビターのためではなかった。この大豆の難消化性 は, 東南アジアの捕虜収容所でとくに顕著であった。し かし大至をテンペにすると，捕虜たらは消化できるよう になった。これは明らかにリゾープスカビの作用による ものであった。多くの戦争捕虜たちが生き延びたいとい ら事実は，大豆がリゾープスで発酵され，テンペにされ たことによる。というのは，たとえ赤琍などで苦しんで いる捕虜たちでさえ，大豆をこのょらにして消化できた からである。」

この記事から，テンペには何か抗生物質的作用があ り，それが，消化系の生体調節機能を果たしたのではな いかと推测される。

\section{(2) ShurtlefF と AOyagi の記述 ${ }^{4}$}

また,ザ・ブックオブテンペには次のよらに書かれて いる。

「WANG $(1972)^{5)}$ は、テンペに医薬的効用があること を見出だした。すなわち、テンぺ菌リゾープスに，抗生 物質ペニシリンと似た方法で，病原菌に対して作用する 天然の，熱安定性のある抗生物質を作る能力があること が見出された。テンペの抗生物質はバクテリア，とくに グラム陽性菌, たとえばぶどう状球菌に効く。ぶどら状 球菌はよくご存じの食中毒菌である。このことからテン
ペを食べることにより，感染に対する抵抗性を高めるこ とがでさるかもしれない。第二次大戦中, インドネシ ア, 香港, シンガボールなど, 東南アジア各地の日本捕 虜収容所で, 赤痢や栄養疾患で悩导捕虜たちの消化器管 を守ったという事実は，この物質が関与していたと考え られる。捕虜の体は煮豆は消化できなかったが，テンペ なら消化でき，そしてついには生き延びることができ た。いくつかの報告によると, 周辺の収容所では, 捕虜 たらは赤痢で悩まされていたにもかかわらず，テンぺを 食べていたところでは, 腸内異常が治り, 驚くほど健康 であった。さらにテンベを常食するインドネシアの人々 は，昔から，テンペは赤痢の薬となることを認識してい た。インドネシアは常に腸内疾患にかかりらる環境であ るが，テンペを食べている人々は，注とんど腸内疾患の 犠牲になることがなかった。WANG の発見は, 衛生状態 が劣悪なため, 感染源が豊富で, 医学的治療が十分でな い貧しい国々にとって，とくに意義ある。」と評価して いる。

これは，テンペに抗生物質的作用があり，それが，消 化系の生体調節機能を果たしていることを明言するもの である。

\section{（3）WANG の研究報告5)}

\section{ーリゾープスの抗菌能の発見一}

では WANG (1972) は, 実際にはどのような研究報告 をしたかとみると、「発酵食品などから分離した種々の カビ（4 属 9 種の 15 株）を, 米, 大豆, 牛乳を基質と し培養した抽出液について，その抗菌能を調べた。牛乳 については，5\% スキムミルク培地でカビを培養し，そ の抽出液を $\mathrm{pH} 5$ に調整し検液とし, 米, 大豆について

第 1 表 発酵食品から分離した系状菌の抗菌性 ${ }^{5}$

\begin{tabular}{|c|c|c|c|c|c|}
\hline \multirow{2}{*}{ 菌 } & \multirow{2}{*}{ 株 } & \multirow{2}{*}{ 採取起源 } & \multicolumn{3}{|c|}{ 阻害ゾーン (mm)a) } \\
\hline & & & 米 & 大 豆 & ミルク \\
\hline Rhizopus oligosporus & NRRL 2710 & テン ペ & 0 & 26.5 & 19. $0^{\mathrm{b})}$ \\
\hline R.oligosporus & NRRL 3271 & テンペ & 0 & 24.0 & $\left.20.0^{b}\right)$ \\
\hline R. chinesis var.liquefaciens & NRRL 2870 & ラ $キ$ & 15.5 & 21.0 & 22.0 \\
\hline R.chinensis & NRRL 3671 & ペーュー & 15.0 & 22.0 & $17.5^{b)}$ \\
\hline R. chinensis & NRRL 5190 & 土＼cjkstart壌 & 14.0 & 23.5 & 24.0 \\
\hline R.oryzae & NRRL 3133 & ラ ギ & 16.0 & 19. 0 & 0 \\
\hline R. javanicus & NRRL 2871 & 輏 油 姆 & 0 & 17.5 & 0 \\
\hline R. chlamydosporus & NRRL 3187 & ベージェ & 0 & 15.0 & 0 \\
\hline Chlamydomucor oryzae & NRRL 5191 & ページェ & 0 & 0 & 0 \\
\hline C. oryzae & NRRL 5192 & ページェ & 0 & 0 & 0 \\
\hline C.oryzae & NRRL 5193 & テンペ & 0 & 0 & 0 \\
\hline C.oryzae & NRRL 5194 & $\neq$ & 0 & 0 & 0 \\
\hline C.oryzae & NRRL 5195 & $キ ゙$ & 0 & 0 & 0 \\
\hline Actinomucor elegans & NRRL 3104 & 腐 & 0 & $\left.29.5^{b}\right)$ & 0 \\
\hline Mucor hiemalis & NRRL 3103 & 乳＼cjkstart噟 & 0 & 0 & 0 \\
\hline
\end{tabular}

a) ペーパーディスクの直径: $12.7 \mathrm{~mm}$ 。被検菌：Bacillus subtilis NRRL B-765。検查培地：ペプトンー 肉エキスーデキストロースー壏類

b) $50 \mathrm{~m} l$ の食塩水で抽出後, 無濃縮。その他は $10 \mathrm{~m} l$ に渋縮。 
は,こうじやテンぺを作る要領で培養 $\left(28^{\circ} \mathrm{C}, 4\right.$ 日間) し たものを, $2 \%$ 食塩水で抽出し, pH 5 に調整し, 検液(米 は $30 \mathrm{~g}$, 大豆は $25 \mathrm{~g}$ から最終的に $10 \mathrm{ml}$ の検液を調製) として調べた。抗菌能は, ペーパーディスク法で, 被検 定菌に, Bacillus subtilis NRRL B-765（グラム陽性細 菌）を用いた。対照とした，2１0\%の食塩水では抗菌能 はみられなかった。第1表のごとく，抗菌能がみられた カビは, R. oligosporus, R. chinensis, R. oryzae, R.javanicus, R.chlamydosporus, Actinomucor elegans であ った。抗菌能は基質によって異なった。たとえば， $R$. chinensis は, 米, 大豆, 牛乳すべてで抗菌能を示した。 R. oligosporus は, 大豆, 牛乳で示したが, 米では示さ なかった。R. oryzae は, 米, 大豆で示し, 牛乳では示 さなかった。R.javanicus, R.chlamydosporus, Actinomucor elegans は, 大豆でのみ示した。Chlamydomucor oryzae と Mucor hiemalis は，いずれでも示さなか った。Bacillus subtilis に対し抗菌能を示したものにつ いて, さらに他の被検定菌, Stapyloccus aureus (グラム 陽性細菌), Agrobacterium tumefaciens (グラム陰性細 菌), Bordetella bronchiseptica (グラム陰性細菌), (グラム陰性細菌)，Mycobacterium smegmatis（酸生 成菌), Mucor ramannianus (カビ), Saccharomyces pastorianus (酵母) で調べたところ, Stapylococcus aureus (グラム陽性細菌) にのみに効果があることが分 からた。すなわち, Bacillus subtilis と Stapylococcus aureus など，グラム陽性細菌のみに効くことが分かっ た。有効成分は, 水や食塭水に可溶で, 有機溶媒には溶 けない。熱安定性があり， $\mathrm{pH} 2 \sim 7$ で安定であった。こ らしたカビに抗菌能が見出だされたことは, 東洋の発酵 食品をよりよく理解するため貴重な発見である。」と結 んでいる。

以上 3 点の記事から，テンペには消化系の抗菌による 生体調節機能があると推定される。しかし，このことを 結論つけるには, 悪玉の腸内細菌に対する効果をさらに 詳しく調べる必要があるかもしれない。

\section{（4）慢性的下痢病による栄養失調からの栄養学的 回復 ${ }^{6)}$}

一消化系の抗菌による生体調節機能の実例一

インドネシアの健康省, 栄養研究開発センターの DARWIN KARYADI は, 以下のことを報告している。発 展途上国では, 栄養失調の改善と下痢の瞢延防止は, 子供 の生命と健康に関わる重要な要因となっている。栄養失 調と病気は複雑にからみあい悪循環する。この悪循環を 断ち切るには, 消化吸収能力を高め, 感染抵抗力や成長 能力を向上させることが重要となる。そこで, 慢性の下 痢患者の消化吸収能力高揚の研究が, ボゴールの健康省
の栄養研究開発センターと, Semarang の Diponegoro 大学小児胃腸部で行われた。その際, テンべを中心とし た食事が，慢性下痢の回復に効果があるかどらか調べら れた。 5 歳以下の慢性下痢の 79 人の子供に, テンペを 中心とした食事を与え, 対照として, 32 人の子供には保 育用ミルクを飲ませた。その結果, テンぺを中心とした 食事の子供は, ミルクを飲ませた子供より，明らかに短 期間で下痢から回復することが示された。慢性のいくつ かのケースでは, 約 2 週間目以降から, 大幅な体重増や, へモグロビンの増加，さらに感染抵抗力の向上が見られ た。たとえば, $5.6 \mathrm{~kg}$ の体重が, 21 日間のテンペを中 心とした食事で, $8.4 \mathrm{~kg}$ に, 同様に $7.2 \mathrm{~kg}$ が 64 日間 で $11.8 \mathrm{~kg}$ に, $6.5 \mathrm{~kg}$ が 21 日間で $7.5 \mathrm{~kg}$ に, $5.0 \mathrm{~kg}$ が 21 日間で $7.8 \mathrm{~kg}$ になった例などが報告されている。

\section{（5） テンぺの整腸作用 ${ }^{7}$}

一消化系の抗菌による生体調節機能を示す 実験例一

さらにテンペの整腸作用について紹介する。CALLOWAY らは，「伝統的・実験的加工法による豆類の腸 内ガス生成能の減少」といら論文で, テンペが, 腸内ガ スの生成を抑制する効果があることを報告している。種 々の豆類とその加工品について行われた実験であるが， 以下テンペに関連した部分のみを紹介する。

被験者は大学に通ら健康な男性で，食物アレルギーは なし。過去最近，大腸に異常なく，抗生物質の投与歴な し。各試験項目の被験者数は一定ではなかったが，少な くとも 4 人立てた。実験順序はランダムに行い，被験者 は1回受けると少なくとも 1 日の試験休みをとった。実 験は数力月に渡った。被験者は，前日の 23 時から飲食 を禁じられ，装朝 9 時（０時間）に30 分間かけて試験 食を摂取した。試験食の掑取カロリーは 800 キロカロリ 一とし, 試料に加总, 無水のバタ一脂肪, シュークロー ス, チーズ, パン, アップルジェリー, オレンジ風味の 饮料ベースで, 実験食の組成とカロリ一が近似するよう 調整した。調整品目は，いずれもガス生成能がないこと が確認されたものである。水分は，カフェイン抜きのコ 一ヒーと, 脱イホン水を与光, 食物からの水と合わせ, $1,000 \mathrm{~g}$ とした。なお 13 時と 17 時に, 栄着学的にバラ ンスのとれたブランド食を 600 キロカロリーを与光，飲 又物は等間隔に与えた。ベースラインを決めるため，こ のブランド食で 800 キロカロリ一試験食を置き換えた ものを用いた。呼気は 30 分ごとに収集し，水素とメ夕 ンをガスクロマトグラフィーで分析した。直腸ガスは 10 時から 18 時まで継続して収集した。その方法は, ガ スの収集もれがないよう，剃った尻にタイゴンチューブ の付いたパッチを固定し，ガス拡散のないプラスチック 
第 2 表 テンペを摂取したヒトの呼気と腸内ガス7)

\begin{tabular}{|c|c|c|c|c|c|c|c|c|c|c|}
\hline \multirow{2}{*}{ 供試 食 } & \multirow{2}{*}{$\begin{array}{c}\text { 量b) }^{(\mathrm{b})} \\
(\mathrm{g})\end{array}$} & \multirow{2}{*}{$\begin{array}{c}\text { 被検者数 } \\
\text { (人) }\end{array}$} & \multicolumn{3}{|c|}{ 呼気中の水素a) } & \multicolumn{5}{|c|}{ 腸 内 ス } \\
\hline & & & $\begin{array}{l}\text { ピーク出現時間 } \\
\text { (摂取後の hr) }\end{array}$ & $\begin{array}{l}\text { 左の漊度 } \\
(\mathrm{ppm})\end{array}$ & 栍算面積( ) & $\begin{array}{c}\text { 全通過量 } \mathrm{d}^{2} \\
(\mathrm{~m} l / 6 \mathrm{hr})\end{array}$ & $\begin{array}{l}\text { 岸酸がス } \\
(\mathrm{ml} / / 6 \mathrm{hr})\end{array}$ & 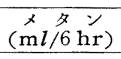 & $\begin{array}{l}\text { 水 } \\
(\mathrm{m} l / 6 \mathrm{hr})\end{array}$ & $\begin{array}{l}\text { 生成速度 } \\
(\mathrm{ml} / \mathrm{h} \mathrm{r})\end{array}$ \\
\hline $\begin{array}{l}\text { ブランド食（基準 } \\
\text { 食） }\end{array}$ & 382 & 28 & $6 \pm 2$ & $14 \pm 9$ & $142 \pm 61$ & $166 \pm 79$ & $4 \pm 3$ & $0.4 \pm 0.8$ & $2 \pm 1$ & 9 \\
\hline ン & 199 & 6 & $9 \pm 1$ & $20 \pm 5$ & $139 \pm 36$ & $169 \pm 50$ & $2 \pm 2$ & $0.4 \pm 0.6$ & $0.8 \pm 0.7$ & 10 \\
\hline $\begin{array}{l}\text { 加熱大豆 (テンペ } \\
\text { のントロール) }\end{array}$ & 200 & 5 & $5 \pm 1$ & $18 \pm 6$ & $175 \pm 68$ & $205 \pm 73$ & $6 \pm 4$ & $2 \pm 2$ & $4 \pm 3$ & 16 \\
\hline 醉素処理大豆 & 344 & 6 & $8 \pm 2$ & $24 \pm 20$ & $190 \pm 115$ & $245 \pm 75$ & $9 \pm 9$ & $2 \pm 3$ & $6 \pm 8$ & 22 \\
\hline 醉絮末 処理大可 & 344 & 6 & $7 \pm 1$ & $28 \pm 6$ & $226 \pm 62$ & $217 \pm 60$ & $7 \pm 4$ & $4 \pm 4$ & $9 \pm 14$ & 18 \\
\hline
\end{tabular}

a) 呼気の水素は腸内細菌によって生成される。

b) 試料の重さ。実験食のカロリーと組成はほぼ等しくなるよう調整後行った。

c) 摂取後 $2.5 \sim 10.5 \mathrm{hr}$ の間の 30 分間隔に測定した面積の積算。

d）全通過量は空気を含を。その量は $110 \pm 27 \mathrm{ml}$ 。

バッグに集まるよらにした。収集した直腸ガスは，マノ メーターで体積を測定し, 炭酸ガス, メタン, 水素など をガスクロマトグラフィーで分析した。テンベに関連し た試料は，テンペと加熱大豆（テンペのコントロール）, 酵素処理大豆と末処理大豆である。供試テンペはバター

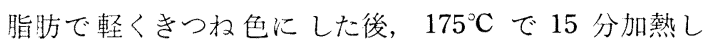
たっそのコントロールはテンベにする前の荒引き大豆を $175^{\circ} \mathrm{C}$ で 20 分加熱した。酵素処理はジアスターゼで行 ったが，大豆をジアスターゼ処理したものは，ラフィ， 一スとスタキオースは汪とんど検出されなかった。末処 理大豆では，ラフィノース，スタキオースがそれぞれ $1.3 \%, 5.0 \%$ 検出された。第 2 表に示すごとく, テンペ は, 呼気中の水素ピークがブランド食の值よりわずかに 高く検出された（ブランド食 14 -テテンヘ $20 \mathrm{ppm}$ )のみ で，呼気中の水素の積算面積（ブランド食 $142 \rightarrow$ テヘ 139），腸内ガス全通過量（ブランド食 $166 \rightarrow$ テベ 169 $\mathrm{ml} / 6 \mathrm{hr}$ ) ならびに生成速度（ブランド食 $9 \rightarrow$ なベ 10 $\mathrm{m} l / \mathrm{hr}$ ) はブランド食とほぼ同じであった。加熱大豆は,

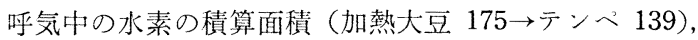

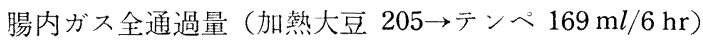
ならびに生成速度（加熱大豆 $16 \rightarrow$ テヘ $10 \mathrm{ml} / \mathrm{hr}$ ) にみ られるように,いずれもテンベより幾分高い值を示した。 また呼気中の水素のピーク出現時間はテンペでは顕著な

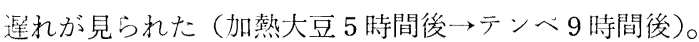
これらの結果から, 大豆ではガスが生成するが, テンベに すると事実上ガス生成能なしと判断されたのみならず, 加熱大豆より 4 時間もがス生成時間を遅らせる作用があ ることが分かった。すなわち，テンべに一時的な整腸作 用の機能があるとの結論である。かれらは，その理由と して, リゾーブスの出す抗生物質 (WANG ら， 1972) を取り上げ，それが腸内のガス生成菌の増殖を抑制して いると推定している。また従来から，豆類を食べると腸 内にガスがたまることはよく知られており, 豆のラフィ ノースやスタキオースにその原因があるとされてきた。 しふし、酵素処理大豆, 酵素未処理大豆とも注注同じ值
を示し(第 2 表参照)，ラフィノースやスタキオースのガ ス生成能は汇とんどないに等しい汇どのものであった。

この報告によると, なぜ大豆はガス生成を促すかにつ いては疑問が深まったが，テンペにするとガス生成が抑 制され，テンペに整腸作用があることが認められる。

\section{2. 抗 酸 化 能}

一発ガンや老化の予防の可能性のある生体調節機能一

発ガンや老化の要因に，脂質の酸化や变異物質によっ て生じた，種々の活性酸素が染色体に損傷を与えること が考えられている。抗酸化性物質は，脂質の酸化を防止 し，活性酸素を失活性する。テンペには抗酸化能がある ことが知られており，したがってテンペには発ガンや老 化の予防といった機能性があるかもしれない。以下，テ ンベの抗酸化能㧍よび抗酸化性物質に関する研究を紹介 する。

\section{（1）抗酸化性物質の研究}

味噌やテンペに抗酸化能があることは, 食品総合研究 所の太田ら $(1964)^{8)}$ が報告しているが，テンペについ ての主要な研究は, アメリカの GYÖRGY のもとで研究 を行った，大阪市大の村田らによりなされた。GYÖRGY $(1960)^{9)}$ は，テンペ粉末と末発酵大豆粉末を，2群の白 ネズミに投与し飼育すると，未発酵大豆粉末を投与した

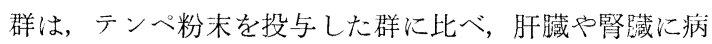
的変化が多く見られることを見出だした。溶血試験の結 果, 貯蔵大豆粉末で飼育した白ネズミの血球は, ジアル 酸で溶血されやすいのに対し，貯蔵テンへで飼育したも のには，そのよらなことは見られなかった。溶血試験と は, ビタミン $\mathrm{E}$ 欠乏のネズミの赤血球膜は, 過酸化物や

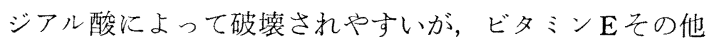
の抗酸化物によって, 溶血が阻止されることを利用した ものである。GYÖRGY, 村田, 池畑 (1964) ${ }^{10)}$ は, テン ペから抗溶血能, 抗酸化能を有すると考兄られる物質を 分離し, ファクター 2 と名付けた。ファクター 2 は, フ ラボノイド類の一つで, 諸性質の比較から，6,7, $4^{\prime}$-トリ 


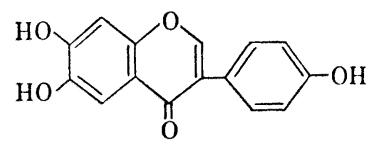

6,7,4'-Trihydroxyisoflavone

第1図 6,7,4'-トリヒドロキシイソフラボン

ヒドロキシイソフラボンと同定された（第 1 忷）。この物 質は, 原料大豆中にはその存在が認められていないので, テンペ製造過程で生成されるものと考えられる。しかし それを化学的に合成し，その効果を調べると， in vivo では，抗酸化性，抗溶血性ともに見られなかった $(1968)^{11}$ 。しかし再三の実験から, 貯蔵テンペ粉末で白 ネズミを飼育すると, テンペ群では大豆群に比べ, 溶血 率, TBA 值（油脂の酸敗の度合いを示す值。チオバルビ ッール酸とカルボニル化合物との反応で呈した色を測定 して得られる）は低く，テンペ群の効果は明らかであっ た $(1971)^{12)} 。$ またキサン:アルコール $=2: 1$ で抽出 したテンペ油は, 大豆, 綿実, コーン, サフラワー, ラ ードなど各種の油に対し，明らかに酸化防止能があるこ とが確認される(1974)。そこでテンペにはもっと油に 溶けやすい別の有効成分もあると考えられ, 油溶性の強 い物質の検索も行われた $\left(1972^{13)}, 1975^{14)}\right)$ 。その結果

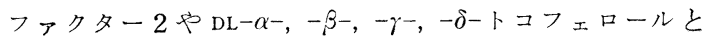
も異なる物質が得られた。

これに対し渡辺 $\left(1984\right.$, 食品工業) ${ }^{15)}$, テンペの抗酸化 能は一物質によるものではなく, 各種抗酸化能物質の相 乗作用によって発現されると説明している。種々のイソ フラボン化合物が, 発酵の過程でその配糖体から加水分 解されてでき，いずれも抗酸化能を有するが，それらが 相乗的にリポキシゲナーゼの作用を阻害する。リポキシ ゲナーゼは不飽和脂肪酸を酸化する酵素である。また大 豆中には種々のトコフェロールもあり, それらは抗酸化 能を有するのみならず, イソフラボン化合物の抗酸化能 を相乗的に高める。この他にサボニン, クロロゲン酸も 存在し, それらも抗酸化能の発揮に加わる。

異分野のことであり，混沌とした印象を受けるが，テ ンペは抗酸化能を有することは間違いなく, 発ガンや老 化の予防の可能性のある機能性があることがらかがえ る。

\section{（2）抗酸化性物質の薬理活性 ${ }^{16)}$}

テンペの抗酸化性物質に関連して, 西ドイッのボン大 学生理化学研究所の H. C. JHA は, 大変興味ある報告を している。かれは, テンぺ抗酸化性物質の薬理活性を, ドイッの Giessen 大学薬病理学部との共同研究で明ら かにした。ファクター2 として知られる，6,7, 4'トリヒ ドロキシイソフラボンやその誘導体に, 血圧低下, 痛
み・炎症・アレルギー抑制作用，さらには浮腫治療効果 があることを見出している。まず，6，7，4'-トリヒドロキ シイソフラボン(この物質のコードネーム JK 485。前掲 の第 1 図参照。 は, カルシウム ionophore-induced 型 の血圧上昇を低下させる作用がある。 $5 \mathrm{mg}$ で効果が現 れ，25 mg で完全にこの原因の血圧ピークを消滅させる 効果が示された。作用機作は JK 485 が血管を拡大する ためである。この効果は, ビタミン Aやその誘導体カル ボキシクロマンの 10 倍ほどの効果であった。次の例 は, アラキドン酸の代謝産物が引き起こす病気に効くと いらものである。アラキドン酸は, 炭素数 20 で, 4 力 所に不飽和をもつ脂肪酸で, 細胞内でいろいろな役割を 果しているが, 酸化されやすく, 酸化されて生じる代謝 産物は, 痛み, 炎症, アレルギーの原因となる。6,7, $4^{\prime}-$ トリヒドロキシイソフラボンに，この酸化を抑制する作

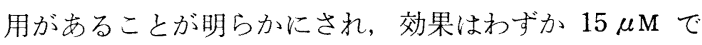
発現した。さらに調べると, アラキドン酸は, リポキシ ゲナーゼとシクロキシゲナーゼの 2 つの経路で酸化され るが，その経路により，また経路の部位により，阻害効 果は異なることが分かった。また 6,7, $4^{\prime}$-トリヒドロキ シイソフラボンの種々の誘導体は, その効果や特暴性が 異なることも分かった。たとえば，ある誘導体はリポキ シゲナーゼ経路に対し， $0.5 \mu \mathrm{M}$ で $50 \%$ の阻害を示し， 他のものはシクロキシゲナーゼ経路に対し， $5 \mu \mathrm{M} て ゙$ $50 \%$ の阻害を示した。さらに別の効果を調べると，種 々の誘導体の中でも， $4^{\prime}$ 部位のメチル型は，母物質の $6,7,4^{\prime}$-トリヒドロキシイソフラボンより安定で，強い 血管縮小抑制効果があることが分かった。すなわち， norepinephrine-iducud 型の血管縮小に対して, ィチル 型 $5 \mu \mathrm{g}$ の投与で効果が現れ，それ以上では完全に血管 縮小を抑制した。したがって，これは薬として使用しら る。Zilliken 1, こ机は 6,7-dihydoxy-methoxyisoflavone を名付けたものであるが， $50 \mu \mathrm{g} / \mathrm{ml}$ で norepinephrine あるいは noradrenaline が原因の血管縮小は完全に消 失した。Zilliken 1 には別の効果も見出された。浮腫と いら病気があるが, Zilliken 1 はこれにも効く。ラット に $50 \mathrm{mg} / \mathrm{kg}$ を静脈投与すると，効き目が現れる。浮腫 には, Dーガラクトサミン型, やけど後遺症型, ガン型の 3 つがあるが，60 匹のラットの実験で効果をみると， ガラクトサミン型の $40 \%$, やけど後遗症型の $13 \%$ に効 果がみられ，Dーガラクトサミン型の浮腫に効果があるこ とが分かった。最後に，イソフラボンは，事実上毒性が ないことが確認された。 $500 \mathrm{mg} / \mathrm{kg}$ をラットに投与して も，いかなる影響がみられなかった。 


\section{3. コレステロール減少効果 ${ }^{6)}$}

さきに, DARWIN KARYADI の発表した，「慢性的下 痢病による栄養失調からの栄養学的回復」を紹介した が,かれはさらに, SOESANTO MANGKUWIDJOJO の研究 (Observation of hypocholesterolemic effects of tempeh. National Symposium on Tempeh. Jakarta, April 15 16, 1985)を次のように紹介している。SOESANTO MANGKUWIDJOJO は, テンペの薬理効果について, 血中コレ ステロールレベルと, 肝藏やラット大動脈の組織学的変 化から検討した。実験は，40 匹のラットを10 匹ずつ 4 つのグループに分けて行った。グループIには, コント ロールとしてコーンミール 100\%を与を, グループIIに は, コーンミール $80 \%$, 豚脂肪 $20 \%$ を与え, グループ IIIには,コーンミール 70\%, 豚脂肪 $10 \%$, テンペ $20 \%$ を与えそとてグループNには，コーンミール 80\%， テンペ $20 \%$ を与えた。慨は自由摂取とし， 2 週間ごと に血中コレステロールを調ベるとともに，4 月月後解剖 し, 肝臓やラット大動脈の組織学的変化を調べだ。その 結果, グループIIに, 血中ュレステロールの増加ととも に, 肝藏やラット大動脈に病的変化が見られたが，他の グループには病的変化はみられなかった。グループNで は, 血中コレステロールの低下に関し，ポジティブな結 果が認められた。かれは, テンペによる血中コレステロ 一ル低下の原因は，レクチン，ナイアシン，シトステロ 一ル,ならびに不飽和脂肪酸によるものではないかと推 定している。

以上, 消化系の抗菌による生体調節機能, 抗酸化能な らびに抗酸化性物質の薬理活性, コレステロール減少効 果について紹介した。なお筆者は, 薬理活性のある生体
調節機能をテンペに求めて, 期待される効果があるので あろらかといら疑いを抱いていたが，こうしてみてくる

と，否定せざるを得ないと考えるよらになった。

$$
\text { <農林水産省熱带農業研究センター> }
$$

\section{文献}

1）荒井綜一：醸協, 85, (1) 2 (1990)

2) 福山忠男 : 食品と科学, 1, 93 (1990)

3) C. W. Hesseltine : Mycologia, 57, 149 (1965)

4) W. ShurtlefF and A. AoyAgi : The Book of Tempeh, Harper \& Low, Publishers, p. 35 (1979)

5) H. L. WANG, J. J. Ellis and C. W. Hesseltine : Mycologia, 64, 218 (1972)

6) D. KARYADI：アジアの無塩発酵大豆食品, 相田 浩, 上田誠之助, 村田希久, 渡辺忠雄編, (STEP 発行), p. 112 (1986)

7) D. H. Calloway, C. A. HiCKey and E. L. MURPHY : J. Food Sci., 36, 251 (1971)

8）太田輝夫, 海老根英雄, 中野政弘 : 食糧研究所報 告, 18, 67 (1964)

9) P. GYÖRGY : Meeting Protein Needs of Infant Children, publication 834, p. 281 (1969)（村 田希久大阪市立大家政紀要，18，19（1971）

10) P.GYÖRGY, K. MURATA and H. IKEHATA : Nature, 203, 870 (1964)

11) H. IKehata, M. WAKAizumi and K. Murata: Agr. Biol. Chem., 32, 740 (1968)

12) K. Murata, H. Ikehata, Y. EdANi and K. Koyanagi : Agr. Biol. Chem., 35, 233 (1971)

13）村田希久, 藤田和子：生化学, 44, 496 (1972)

14）福山美穂, 平井和子, 村田希久：生化学, 47, 771 (1975)

15）渡辺忠雄 : 食品工業, 6 下, p. 35 (1984)

16） H. C. JHA：アジアの無塩発酵大豆食品, 相田浩, 上田誠之助, 村田希久, 渡辺忠雄, (STEP 発 行), p. 199 (1986)

\section{執筆者紹介(順不同・敬称略)}

岡田 憲幸 $<$ Noriyuki OKADA $>$

昭和 22 年 6 月 5 日生れ<勤務先とその所在地 $>$ 農水省 熱帯農業研究センター, 干305 茨城県つくば市大わし $1-2<$ 略歴>昭和 50 年名古屋大学修士課程農学研究科修 了, 50 年農水省食品総合研究所入所, 平成 2 年 4 月よ り農水省熱帯農業研究センター<抱負>発酵食品につい て，より深い知見を得たいく趣味〉テニス，家庭菜園， 近じかゴルフを始めたいと思っている。

\section{高田 善浩 $<$ Yoshihiro TAKATA $>$}

昭和35年 8 月 6 日生れ<勤務先とその所在地>サッポ ロビール(株)醇造技術研究所, $\bar{T} 425$ 静岡県焼津市岡当 目 $10<$ 略歴 $>$ 昭和 58 年東京大学農学部農芸化学科卒, 59 年サッポロビール(株)入社, 中央研究所 (現醸造技術研 究所）勤務，63年 4 月より本年 3 月まで(株)醸造資源研 究所に出向の後, 現在に至るく抱負>おいしいビールを 産みだす酵母とはなにかを分子生物学的に追求すること く趣味>スキー, 音楽鑑賞, おいしい酒を拈いしい看で 飲もこと。 